\title{
Possible interplay between interleukin-15 and interleukin-17 into the pathogenesis of idiopathic inflammatory myopathies
}

\author{
A. Notarnicola ${ }^{1,2}$, G. Lapadula ${ }^{1}$, D. Natuzzi ${ }^{1}$, F. lannone ${ }^{1}$ \\ ${ }^{1}$ DIM - Rheumatology Unit, Medical School, University of Bari; \\ ${ }^{2}$ Rheumatology Unit, Department of Medicine, Karolinska Institutet at Karolinska University Hospital, \\ Solna Stockholm, Sweden
}

\begin{abstract}
The aim of this study was to assess the serum levels of interleukin (IL)-15 and IL-17 in patients with idiopathic inflammatory myopathies (IIM) and correlate them with IL-6, IL-10, monocyte chemoattractant protein-1 (MCP-1), macrophage inflammatory protein-1 $\alpha$ (MIP-1 $\alpha)$, MIP-1 $\beta$ levels. Possible correlations with disease activity parameters were also evaluated.

Sera from 14 polymyositis (PM), 10 dermatomyositis (DM), 7 anti-synthetase syndrome new onset patients and 19 healthy controls (HCs) were analyzed by multiplex immunoassay. Sera from 19 patients were analyzed after 5 months median follow-up. All patients underwent physical examination, the 5-points manual muscle test (MMT), the health assessment questionnaire and serum creatine kinase measurement. All patients received glucocorticoids, and 13 were taking also immunosuppressive therapy.

At baseline, serum levels of IL-15, IL-17, MCP-1 and MIP-1 $\beta$ were significantly higher in IIM patients than in HCs. IL-17 serum levels were directly correlated with disease duration $(\mathrm{r}=0.39, \mathrm{P}=0.02)$, while a significant inverse correlation was detected between IL-17 levels and MMT scores ( $\mathrm{r}=-0.4, \mathrm{P}=0.02)$. The highest IL-15 levels were present in $\mathrm{DM}$ patients $(\mathrm{P}=0.02$ vs $\mathrm{PM})$. The most striking finding was the strong correlation between IL-15 and IL-17 levels $(r=0.60, P=0.0001)$, and this correlation was even stronger in DM patients $(r=0.82$, $\mathrm{P}=0.006)$.

The strong correlation between IL-15 and IL-17 in IIM patients, and especially in DM, suggests that there may be a interplay between the two cytokines in the pathogenesis of myositis. Further studies of larger patient cohorts and muscle biopsies are needed to confirm these preliminary data.
\end{abstract}

Key words: Interleukin (IL)-15, IL-17 isoform A, IL-6, IL-10, Monocyte chemoattractant protein-1, Macrophage inflammatory protein $(M I P)-1 \alpha, M I P-1 \beta$, Idiopathic inflammatory myopathies.

Reumatismo, 2014; 66 (3): 215-223

\section{INTRODUCTION}

diopathic inflammatory myopathies (IIM), including polymyositis (PM) and dermatomyositis (DM), are heterogeneous diseases occurring with proximal symmetrical muscle weakness, increased serum muscle enzymes, inflammatory infiltrates on muscle biopsy and specific skin lesions $(1,2)$. IIM can also be sub-classified on the basis of the auto-antibody profile. Among myositis-specific auto-antibodies, those targeting aminoacyl-tRNA synthetases have been associated with a specific clinical phenotype, the so-called anti-synthetase syndrome (ASS), anti-Jo-1 being the most frequent antibody (3-5).

Even if the pathogenesis of IIM is not yet fully understood, many authors suggest that an active role may be played by cytokines found both in muscle tissue and peripheral blood, including interleukin (IL)-15, IL17, IL-6, IL-10, monocyte chemoattractant protein-1 (MCP-1), macrophage inflammatory protein- $1 \alpha$ (MIP- $1 \alpha$ ), and MIP- $1 \beta$ (6-19). Recently, IL-15 and IL-17 have emerged as candidate mediators of induction/expansion of the pro-inflammatory cytokine cascade in IIM, and systemic or muscle production of IL-15 and IL-17 has been demonstrated in patients affected by IIM (20-22). IL-15, originally identified as $\mathrm{T}$ cell activating factor, is widely expressed in human tissues including skeletal muscle, but it is rarely detected in healthy conditions. It participates in the development
Conference presentation: L SIR Congress, 2013.
Corresponding author: Florenzo lannone DIM - Rheumatology Unit Policlinico

Piazza G. Cesare, 11 - 70124 Bari, Italy E-mail: florenzo.iannone@uniba.it 
of natural killer cells, binding its unique receptor shared with IL-2. IL-15 has been reported to be increased in autoimmune or inflammatory diseases, such as in the synovial fluid or membrane of rheumatoid arthritis (RA) patients (23-25). In PM and DM, IL-15 and its receptor have been found in muscle tissue, and high serum levels have also been detected $(11,20,22)$. It is well known that the T helper 17 pathway is one of the most important mechanisms inducing and maintaining chronic inflammation (26). In IIM, IL-23 and IL-17 amplify the immune response by activating monocytes and innate immunity, ultimately leading to muscle destruction $(21,27)$. In RA, a strong correlation between IL-15 and IL-17 has been found, as IL-15 induces the $\mathrm{T}$ cells to produce $\mathrm{IL}-17$ which stimulates synoviocytes to release pro-inflammatory mediators (28). To our knowledge, in IIM a possible interaction between IL-15 and IL17 has not previously been explored. In this study we aimed at evaluating the behavior of IL-15 and IL-17 serum levels and correlating them with the other cytokines involved in the pathogenesis of muscle damage in PM, DM and ASS patients at baseline and follow-up. In addition, possible correlations with scores of the 5 points-manual muscle test (5-MMT), health assessment questionnaire (HAQ) and creatine kinase $(\mathrm{CK})$ were assessed.

\section{MATERIALS AND METHODS}

\section{Patients}

The study included 31 consecutively enrolled Caucasian patients affected by IIM [26 women, 5 men (mean age \pm standard deviation, $S D) 58.8$ years \pm 2.1 ]. According to Bohan and Peter criteria $(29,30)$, definite PM was diagnosed in 14, definite DM in 10 , and 7 patients were classified as having ASS anti-Jo-1 positive (ASS anti-Jo-1+ve) (31). Only three of the 7 ASS anti-Jo-1+ve patients had myositis, 2 PM and $1 \mathrm{DM}$. The control group included 19 healthy controls (HCs) (16 women, 3 men, mean age \pm SD of 45.8 years \pm 1.8 ). We defined as baseline the time the patient was enrolled in the study. At baseline the median disease duration was 12 months, and the patients were longitudinally followed with regular check-ups. Prior approval of the study was obtained from the local ethics committee and patients were enrolled after giving written informed consent in accordance with the Helsinki declaration.

All patients underwent physical examination, the total MMT (group of 24 proximal, distal, and axial muscles assessed bilaterally) scored by the 5-points Medical Research Council scale (32) generated a final score as a result of the average of all muscles tested scores, HAQ (33) and routine blood tests including CK assessed by ELISA (normal values 84-199 U/L). At baseline, serum was obtained from each patient, and frozen at $-80^{\circ} \mathrm{C}$ until use. A second sample was obtained after a median followup of 5 months in 19 patients. Patients demographic, clinical and laboratory data are summarized in Table I.

At baseline, all patients were taking low doses of glucocorticoids [median $5 \mathrm{mg}$ daily, inter-quartile range (IQR) 5.6]. 13 patients were also treated with disease modifying anti-rheumatic drugs (DMARDs), 5 with azathioprine (AZA), 3 with methotrexate (MTX), 1 with cyclosporine A (CYC), 3 with a combination of MTXAZA and 1 with a combination of CYCMTX. The other 18 were DMARDs-free.

\section{Serum cytokines measurement}

Multiplex immunoassay (Bioplex 200 System, Bio-Rad Lab., Hercules, CA, USA) was used to simultaneously measure the serum levels of IL-6, IL-10, IL-15, IL-17 isoform A, MCP-1, MIP- $1 \alpha$ and MIP- $1 \beta$ in all patients and HCs. We used the commercial human antibodies kit produced by Bio-Rad (Bioplex Pro ${ }^{\mathrm{TM}}$ Cytokine Assay, 1 x 96 well 9-plex Group I, Bio-Rad). The assay was performed according to the manufacturer's instructions. The ranges of measurability of the standard curve were $0.07-19,147 \mathrm{pg} /$ $\mathrm{mL}$ for IL-6, 0.11-28,093 pg/mL for IL-10, $0.1-24,906 \mathrm{pg} / \mathrm{mL}$ for IL-15, 0.08-21,505 $\mathrm{pg} / \mathrm{mL}$ for IL-17, $0.09-23,735 \mathrm{pg} / \mathrm{mL}$ for MCP-1, $0.08-21,778 \mathrm{pg} / \mathrm{mL}$ for MIP-1 $\alpha$ and $0.08-20,198 \mathrm{pg} / \mathrm{mL}$ for MIP- $1 \beta$. 
Table I - Disease characteristics of the patients at baseline and follow-up.

\begin{tabular}{|c|c|c|c|c|c|c|c|c|c|c|c|c|c|c|c|c|c|c|c|c|}
\hline t & 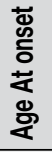 & 高 & 苞 & ס & $\begin{array}{l}\text { 운 } \\
\text { o } \\
\text { 妾 }\end{array}$ & 竞 & 号 & 只 & 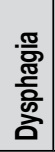 & $\begin{array}{l}\text { ঠ্ } \\
\text { ट্ঠঁ }\end{array}$ & $\begin{array}{l}\text { 范 } \\
\stackrel{\bar{n}}{0} \\
\stackrel{\oplus}{\Delta}\end{array}$ & $\begin{array}{l}\text { 응 } \\
\text { के } \\
\text { के }\end{array}$ & 总 & 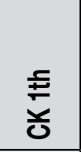 & $\sum_{\sum}^{F}$ & 豆 & 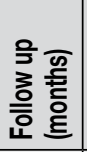 & $\begin{array}{l}\text { 오 } \\
\text { ড̀ }\end{array}$ & 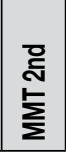 & $\begin{array}{l}\text { 은 } \\
\text { 운 } \\
\text { 소 }\end{array}$ \\
\hline 1 & 50 & $\mathrm{~F}$ & Caucasian & $\begin{array}{l}\text { ASS } \\
\text { Jo-1+ }\end{array}$ & $\begin{array}{l}\text { ANAt, anti SSAt, } \\
\text { anti Jo1+ }\end{array}$ & yes & yes & yes & yes & no & 132 & 7.5 & $\begin{array}{l}\text { MTX- } \\
\text { AZA-lg }\end{array}$ & 389 & 4.24 & 1.75 & & & & \\
\hline 2 & 56 & $\mathrm{~F}$ & Caucasian & $\begin{array}{l}\text { ASS } \\
\text { Jo-1+ }\end{array}$ & ANA+, anti Jo1+ & no & no & yes & yes & no & 60 & 5 & & 151 & 4.71 & 1.12 & & & & \\
\hline 3 & 48 & $\mathrm{~F}$ & Caucasian & $\begin{array}{l}\text { ASS } \\
\text { Jo-1+ }\end{array}$ & $\begin{array}{l}\text { anti SSA+, } \\
\text { anti Jo-1+ }\end{array}$ & no & no & yes & no & no & 12 & 10 & & 533 & 4.69 & 2.12 & & & & \\
\hline 4 & 70 & $F$ & Caucasian & $\begin{array}{l}\text { ASS } \\
\text { Jo-1+ }\end{array}$ & ANA+, anti Jo-1+ & no & yes & yes & no & no & 4 & 10 & & 68 & 4.83 & 0.37 & 11 & 87 & 4.65 & 0.37 \\
\hline 5 & 51 & $F$ & Caucasian & $\begin{array}{l}\text { ASS } \\
\text { Jo-1+ }\end{array}$ & ANA+, anti Jo-1+ & yes & no & yes & no & no & 12 & 5 & & 83 & 4.36 & 2.37 & 5 & 51 & 4.36 & 1.37 \\
\hline 6 & 50 & $F$ & Caucasian & $\begin{array}{l}\text { ASS } \\
\text { Jo-1+ }\end{array}$ & $\begin{array}{l}\text { ANAt, anti SSAt, } \\
\text { anti Jo- } 1_{+}\end{array}$ & yes & yes & yes & no & no & 6 & 10 & $\begin{array}{l}\text { CYC- } \\
\text { MTX }\end{array}$ & 58 & 4.9 & 0.25 & 6 & 31 & 5 & 1.75 \\
\hline 7 & 66 & $F$ & Caucasian & $\begin{array}{l}\text { ASS } \\
\text { Jo-1+ }\end{array}$ & $\begin{array}{l}\text { ANAt, anti SSAt, } \\
\text { anti Jo-1+ }\end{array}$ & yes & yes & yes & no & no & 17 & 25 & & 712 & 4.73 & 1.37 & 5 & 301 & 4.73 & 1.12 \\
\hline 8 & 58 & $\mathrm{~F}$ & Caucasian & DM & ANA+, anti TIF1 $\gamma+$ & no & yes & no & yes & yes & 2 & 10 & 81 & & & & & & & \\
\hline 9 & 48 & $\mathrm{~F}$ & Caucasian & $\mathrm{DM}$ & ANAt, anti Mi-2t & no & yes & yes & no & no & 36 & 25 & MTX & 186 & 4.87 & 0.87 & & & & \\
\hline 10 & 84 & $F$ & Caucasian & DM & $\begin{array}{c}\text { ANA+, } \\
\text { anti SAE1-2+ }\end{array}$ & no & yes & yes & no & no & 1 & 25 & & 58 & 4.24 & 1.75 & & & & \\
\hline 11 & 72 & $F$ & Caucasian & DM & $\begin{array}{l}\text { ANA }+ \text {, anti SSAt, } \\
\text { anti SAE1-2+ }\end{array}$ & no & yes & yes & no & no & 8 & 10 & CYC & 21 & 4.29 & 1.75 & & & & \\
\hline 12 & 66 & $\mathrm{~F}$ & Caucasian & $\mathrm{DM}$ & ANAt & no & yes & yes & no & no & 1 & 5 & & 59 & 4.35 & 2.12 & 9 & 85 & 4.5 & 1.75 \\
\hline 13 & 65 & $F$ & Caucasian & DM & ANAt & no & yes & no & yes & no & 9 & 25 & $\begin{array}{l}\text { MTX- } \\
\text { AZA }\end{array}$ & 201 & 3.6 & N.A. & & & & \\
\hline 14 & 41 & $\mathrm{~F}$ & Caucasian & $\mathrm{DM}$ & ANAt, anti SAE2+ & no & yes & no & yes & no & 3 & 5 & & 170 & 3.85 & N.A. & 5 & 110 & 3.85 & N.A \\
\hline 15 & 49 & $\mathrm{~F}$ & Caucasian & $\mathrm{DM}$ & None & no & yes & no & no & no & 15 & 2.5 & AZA & 74 & 4.65 & 1.12 & 5 & 84 & 5 & 1.12 \\
\hline 16 & 60 & $M$ & Caucasian & $\mathrm{DM}$ & None & no & yes & yes & yes & no & 15 & 5 & & 18 & 4.7 & 0.62 & 4 & 94 & 4.75 & 0.62 \\
\hline 17 & 45 & $F$ & Caucasian & $\mathrm{DM}$ & None & no & yes & no & yes & yes & 4 & 25 & & 151 & 3.46 & 2.75 & 4 & 127 & 4.5 & 0.87 \\
\hline 18 & 69 & $F$ & Caucasian & PM & ANAt & yes & no & yes & yes & no & 1 & 5 & & 205 & 3.33 & 2.87 & & & & \\
\hline 19 & 33 & $M$ & Caucasian & PM & $\begin{array}{l}\text { ANAt, anti Pm- } \\
\text { Scl+, anti Scl70+ }\end{array}$ & no & yes & yes & no & no & 7 & 12.5 & $\begin{array}{l}\text { MTX- } \\
\text { AZA }\end{array}$ & 574 & 5 & 0.62 & 16 & 105 & 4 & N.A. \\
\hline 20 & 46 & $F$ & Caucasian & PM & ANAt & yes & no & yes & yes & no & 36 & 2.5 & & 385 & 2.72 & 3 & & & & \\
\hline 21 & 67 & $F$ & Caucasian & PM & $\begin{array}{l}\text { ANAt, anti } \\
\text { Pm-Sclt, } \\
\text { anti Scl70+ }\end{array}$ & no & no & yes & yes & no & 11 & 25 & $\begin{array}{l}\text { MTX- } \\
\text { AZA }\end{array}$ & 881 & 4.5 & N.A. & 16 & 191 & 5 & N.A. \\
\hline 22 & 56 & $M$ & Caucasian & PM & $\begin{array}{l}\text { ANA+, anti SSA+, } \\
\text { anti Pm-Scl+ }\end{array}$ & no & no & no & yes & no & 4 & 25 & & 3210 & 3 & N.A. & 1 & 122 & 3.9 & N.A \\
\hline 23 & 58 & $F$ & Caucasian & PM & $\mathrm{ANA}_{+}$, anti SSAt & no & no & yes & yes & no & 108 & 5 & AZA & 250 & 3.86 & 2.25 & & & & \\
\hline 24 & 44 & $F$ & Caucasian & PM & None & yes & no & no & no & yes & 1 & 5 & & 11706 & 4.87 & 1.12 & 12 & 70 & 4.9 & 0.75 \\
\hline 25 & 40 & $\mathrm{~F}$ & Caucasian & PM & ANAt & no & no & yes & yes & no & 84 & 5 & AZA & 98 & 4.69 & 2.5 & & & & \\
\hline 26 & 36 & $\mathrm{~F}$ & Caucasian & PM & $\mathrm{ANA}_{+}$, anti SSAt & yes & no & yes & yes & no & 72 & 2.5 & MTX & 582 & 4.8 & 1.2 & 20 & 138 & 4.83 & 1.5 \\
\hline 27 & 67 & $M$ & Caucasian & PM & None & no & no & no & yes & no & 14 & 5 & MTX & 324 & 4.44 & 1.5 & 20 & 143 & 4.68 & 0.75 \\
\hline 28 & 64 & $\mathrm{~F}$ & Caucasian & PM & None & no & no & no & no & no & 12 & 5 & AZA & 438 & 4.31 & 0.12 & 21 & 288 & 4.9 & 0.25 \\
\hline 29 & 52 & $\mathrm{~F}$ & Caucasian & PM & None & no & no & no & yes & no & 36 & 5 & & 327 & 4.37 & 1.75 & 5 & 228 & 4.71 & 1.75 \\
\hline 30 & 76 & $F$ & Caucasian & PM & ANAt, anti SSAt & no & no & yes & no & no & 1 & 10 & & 1161 & 4.86 & 2.75 & 4 & 106 & 4.95 & 0.87 \\
\hline 31 & 78 & $M$ & Caucasian & PM & None & no & no & no & no & no & 1 & 5 & & 918 & 4.86 & 1.12 & 4 & 378 & 4.5 & 1.12 \\
\hline
\end{tabular}

Pt, patient; Dg, diagnosis; AutoAb, autoantibodies; Skin involv., skin involvement; ILD, interstitial lung disease; Dis. Durat., disease duration (months); DMARDs, disease modified anti rheumatic drugs; CK 1th, creatine kinase first sample; MMT 1th, manual muscle test first sample; HAQ 1th, health assessment questionnaire first sample; CK 2nd, CK second sample; MMT 2nd, MMT second sample; HAQ 2nd, HAQ second sample; PM, polymyositis; DM, dermatomyositis; ASS Jo1+, anti synthetase syndrome Jo1 positive; Steroid, prednisone (mg/day); AZA, azathioprine; MTX, methotrexate; CYC, cyclosporine; N.A., not available. 


\section{Statistical analysis}

A normal distribution of continuous variables was estimated by KolmogorovSmirnov test. Continuous variables were calculated as means plus 1 SD if normally distributed, whereas medians and IQR range were calculated for not normallydistributed continuous variables. For categorical variables, counts and percentages were calculated. Differences in means for normally distributed continuous variables were compared by analysis of variance (ANOVA), while the Kruskal-Wallis test was used to compare not normally-distributed continuous variables. Within-group comparisons between baseline and followup results were evaluated by the Wilcoxon signed-rank test. Spearman's rank correlation test was used to correlate not normally-distributed variables, and the Pearson correlation test for normally-distributed variables. Partial correlation analysis was carried out to study the relationship between two variables after excluding the effect of one or more independent factors. Statistical analyses were done using the SPSS (version 20) statistical software; P values $<0.05$ were considered statistically significant.

\section{RESULTS}

\section{Clinical assessment}

With respect to the group of patients, at baseline (Tab. I), the median CK level was 325.5 U/L (IQR 691), the median MMT and HAQ scores were 4.67 (IQR 0.4) and
1.28 (IQR 1.1), respectively. CK levels dropped significantly from baseline (median 325.5 U/L, IQR 691) to follow-up (median 116.5 U/L, IQR 158, P=0.001). Neither MMT nor HAQ were significantly different between baseline and follow-up. Furthermore, CK levels did not correlate with MMT ( $\mathrm{r}=0.10, \mathrm{P}=0.4)$ and an inverse correlation was also detected between MMT and HAQ ( $\mathrm{r}=-0.65, \mathrm{P}=0.0001)$.

\section{Cytokines measurement}

At baseline (Tab. II), IL-15 serum levels were significantly higher in IIM patients (median $1.12 \mathrm{pg} / \mathrm{mL}$, IQR 5.6) than in HCs (median $0.41 \mathrm{pg} / \mathrm{mL}, \mathrm{IQR} 1.5, \mathrm{P}=0.01$ ). IL-17 levels were also significantly higher in patients (median $4.23 \mathrm{pg} / \mathrm{mL}$, IQR 5.5) than in HCs (median $1.44 \mathrm{pg} / \mathrm{mL}$, IQR 1.3 , $\mathrm{P}=0.009$ ). Higher serum levels of MCP-1 and MIP-1 $\beta$ were detected in IIM patients (median $82.81 \mathrm{pg} / \mathrm{mL}$, IQR 79.4 and median $120.03 \mathrm{pg} / \mathrm{mL}$, IQR 57, respectively) than in HCs (median $35.53 \mathrm{pg} / \mathrm{mL}$, IQR 26.4 and median $83.01 \mathrm{pg} / \mathrm{mL}$, IQR 43.9, respectively), and this difference was statistically significant $(\mathrm{P}=0.001$ and $\mathrm{P}=0.03$, respectively).

Concerning IL-6 and IL-10, no statistically significant differences between IIM patients and HCs have been found. Comparing cytokines serum levels of IIM patients at baseline and follow-up, no significant differences were found.

We assessed whether the serum levels of all cytokines were influenced by glucocorticoids and the clinical parameters at baseline (Tab. III). We found a direct corre-

Table II - Cytokines serum levels at baseline and follow-up.

\begin{tabular}{|l|c|c|c|c|c|}
\hline & $\begin{array}{c}\text { Patients } \\
\text { (baseline) } \\
\text { Median (IQR) }\end{array}$ & $\begin{array}{c}\text { Patients } \\
\text { (follow-up) } \\
\text { Median (IQR) }\end{array}$ & $\begin{array}{c}\text { P } \\
\text { (baseline } \\
\text { vs follow-up) }\end{array}$ & $\begin{array}{c}\text { HC } \\
\text { Median } \\
\text { (IQR) }\end{array}$ & $\begin{array}{c}\text { P } \\
\text { (baseline vs HC) }\end{array}$ \\
\hline IL-6 & $3.40(8.8)$ & $3.17(3.9)$ & 0.23 & $1.24(2.1)$ & 0.051 \\
\hline IL-10 & $1.94(1.3)$ & $1.5(1.7)$ & 0.31 & $1.35(3.3)$ & 0.47 \\
\hline IL-15 & $1.12(5.6)$ & $1.12(0.7)$ & 0.72 & $0.41(1.5)$ & 0.01 \\
\hline IL-17 & $4.23(5.5)$ & $1.44(0.4)$ & 0.48 & $1.44(1.3)$ & 0.009 \\
\hline MCP-1 & $82.81(79.4)$ & $62.29(106.1)$ & 0.06 & $35.53(26.4)$ & 0.001 \\
\hline MIP-1a & $0.35(0.8)$ & $0.35(0.6)$ & 0.20 & $0.35(0)$ & 0.46 \\
\hline MIP-1b & $120.03(57)$ & $122.14(85)$ & 0.15 & $83.01(43.9)$ & 0.03 \\
\hline
\end{tabular}

$\mathrm{HC}$, healthy control; IQR, inter-quartile range; IL-6, -10, -15, -17, interleukin-6, -10, -15, -17; MCP-1, monocyte chemoattractant protein-1; MIP-1 $\alpha,-1 \beta$, macrophage inflammatory protein $-1 \alpha,-1 \beta$. 
Table III - Correlation coefficients $(r)$ and significance values $(P)$ between cytokines serum levels and clinical parameters at baseline.

\begin{tabular}{|l|c|c|c|c|c|c|c|c|c|c|}
\hline & \multicolumn{2}{|c|}{ Steroid dosage } & \multicolumn{2}{|c|}{ CK } & \multicolumn{2}{c|}{ MMT } & \multicolumn{2}{c|}{ HAQ } & \multicolumn{2}{c|}{ Disease duration } \\
\hline & $\mathbf{r}$ & $\mathbf{P}$ & $\mathbf{r}$ & $\mathbf{P}$ & $\mathbf{r}$ & $\mathbf{P}$ & $\mathbf{r}$ & $\mathbf{P}$ & $\mathbf{r}$ & $\mathbf{P}$ \\
\hline IL-6 & 0.33 & 0.07 & -0.04 & 0.81 & 0.023 & 0.90 & -0.04 & 0.84 & -0.11 & 0.45 \\
\hline IL-10 & 0.43 & 0.01 & -0.07 & 0.69 & 0.03 & 0.86 & 0.1 & 0.62 & -0.27 & 0.14 \\
\hline IL-15 & 0.27 & 0.13 & -0.10 & 0.56 & -0.27 & 0.13 & 0.32 & 0.11 & -0.22 & 0.22 \\
\hline IL-17 & 0.24 & 0.17 & 0.03 & 0.84 & -0.40 & 0.02 & 0.19 & 0.33 & 0.39 & 0.02 \\
\hline MCP-1 & 0.22 & 0.26 & -0.24 & 0.22 & 0.12 & 0.54 & 0.16 & 0.44 & -0.12 & 0.53 \\
\hline MIP-1 $\alpha$ & 0.39 & 0.02 & 0.01 & 0.92 & -0.25 & 0.16 & -0.18 & 0.37 & -0.29 & 0.10 \\
\hline MIP-1 $\beta$ & 0.02 & 0.89 & 0.17 & 0.36 & -0.29 & 0.12 & 0.30 & 0.14 & 0.42 & 0.02 \\
\hline
\end{tabular}

$\mathrm{CK}$, creatine kinase; MMT, manual muscle test; HAQ, health assessment questionnaire; IL-6, $-10,-15$, -17 , interleukin-6, -10, -15, -17; MCP-1, monocyte chemoattractant protein-1; MIP-1 $\alpha,-1 \beta$, macrophage inflammatory protein-1 $\alpha,-1 \beta$.

lation between IL-17 and disease duration $(\mathrm{P}=0.02)$, and an inverse correlation between IL-17 and MMT (r:-0.40, P=0.02). No correlation between cytokine serum levels and Jo-1 positivity has been found. All patients were receiving glucocorticoids and a direct correlation between the daily dosage of prednisone and IL-10 $(r=0.43$, $\mathrm{P}=0.01)$, and MIP- $1 \alpha(\mathrm{r}=0.39, \mathrm{P}=0.02)$ levels was detected. No correlations between DMARDs intake and the serum levels of all cytokines were found.

At entry, IL-17 was the only cytokine found to correlate with disease activity as MMT score was inversely correlated to IL-17 serum levels $(\mathrm{r}=-0.40, \mathrm{P}=0.02)$. To assess whether IL-17 varied depending on the MMT over time, we pooled baseline and follow-up cytokine values and correlated them with MMT scores. Notably, a significant inverse correlation (Fig. 1) was found between IL-17 levels and MMT scores ( $\mathrm{r}=-$ $0.36, \mathrm{P}=0.009$ ).

We also looked for possible different patterns of cytokines among the three subsets of myositis. IL-17 levels did not differ among PM, DM and ASS Jo-1+ve patients. The median IL-15 concentration was 8.8 $\mathrm{pg} / \mathrm{mL}$ (IQR 12.2) in DM, $1.12 \mathrm{pg} / \mathrm{mL}$ (IQR 0.7) in PM, and $1.12 \mathrm{pg} / \mathrm{mL}$ (IQR 5.8) in ASS Jo-1+ve, but the difference was statistically significant only between DM and $\mathrm{PM}(\mathrm{P}=0.02)$ (Fig. 2).

Finally, we searched for possible relationships among cytokines in all IIM patients at baseline. Because of the correlation of IL-17 with disease duration, the latter con- founder was removed by applying partial correlation analysis. The most striking finding was the strong correlation between IL-15 and IL-17 levels ( $\mathrm{r}=0.60, \mathrm{P}=0.0001)$. In patients affected by DM, the correlation between IL-15 and IL-17 was found to be even stronger $(\mathrm{r}=0.82, \mathrm{P}=0.006)$, as shown in Figure 3. No correlation between IL-15 and IL-17 in HCs was found

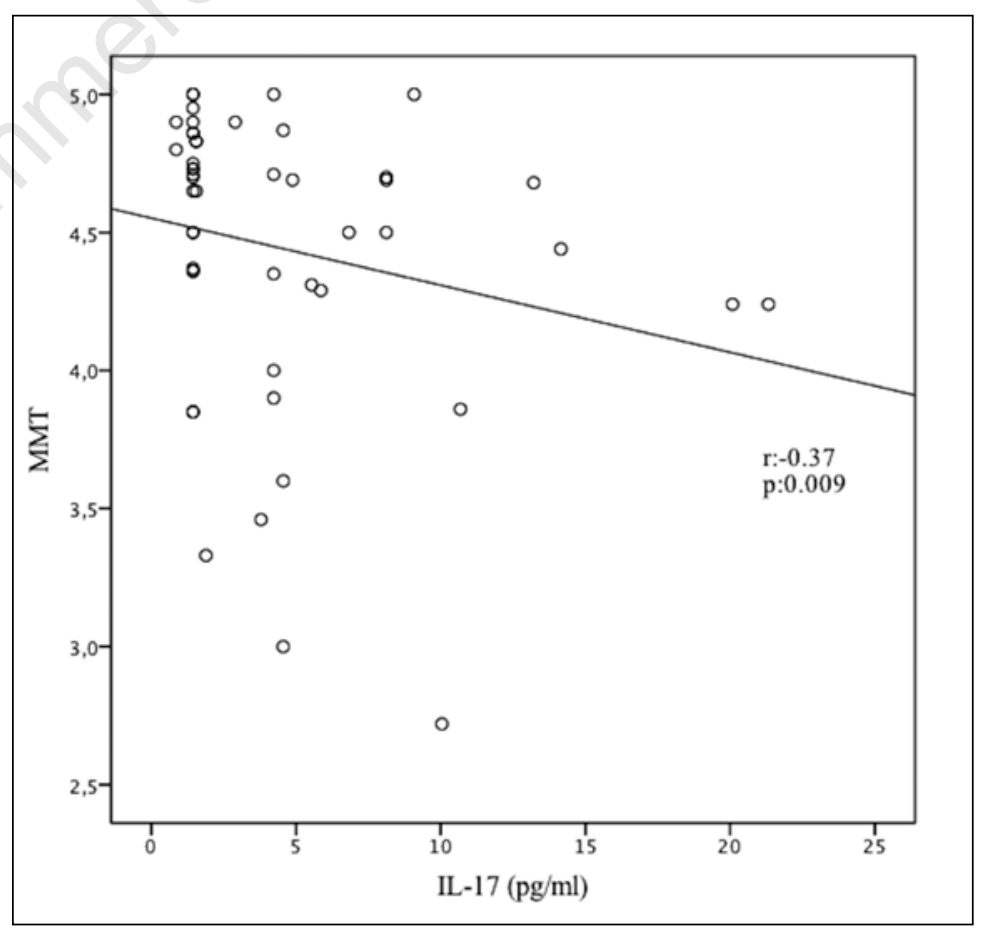

Figure 1 - Correlation analysis between the manual muscle test (MMT) score and interleukin (IL)-17 serum levels of idiopathic inflammatory myopathies patients. Baseline and follow-up data were pooled. 


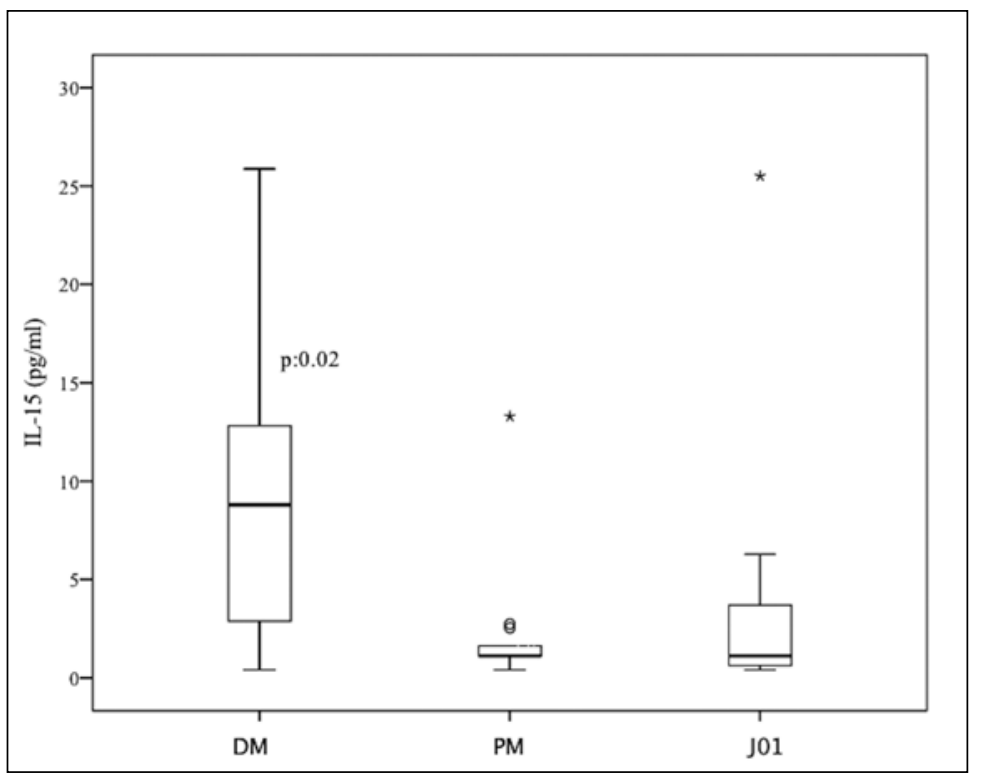

Figure 2 - Comparison of interleukin (IL)-15 serum levels among dermatomyositis (DM), polymyositis (PM), and Jo-1 anti-synthetase syndrome (ASS anti-Jo-1+ve) patients at baseline. Box plots represent medians, 25th and 75th percentiles, and whiskers 10th and 90th percentiles.

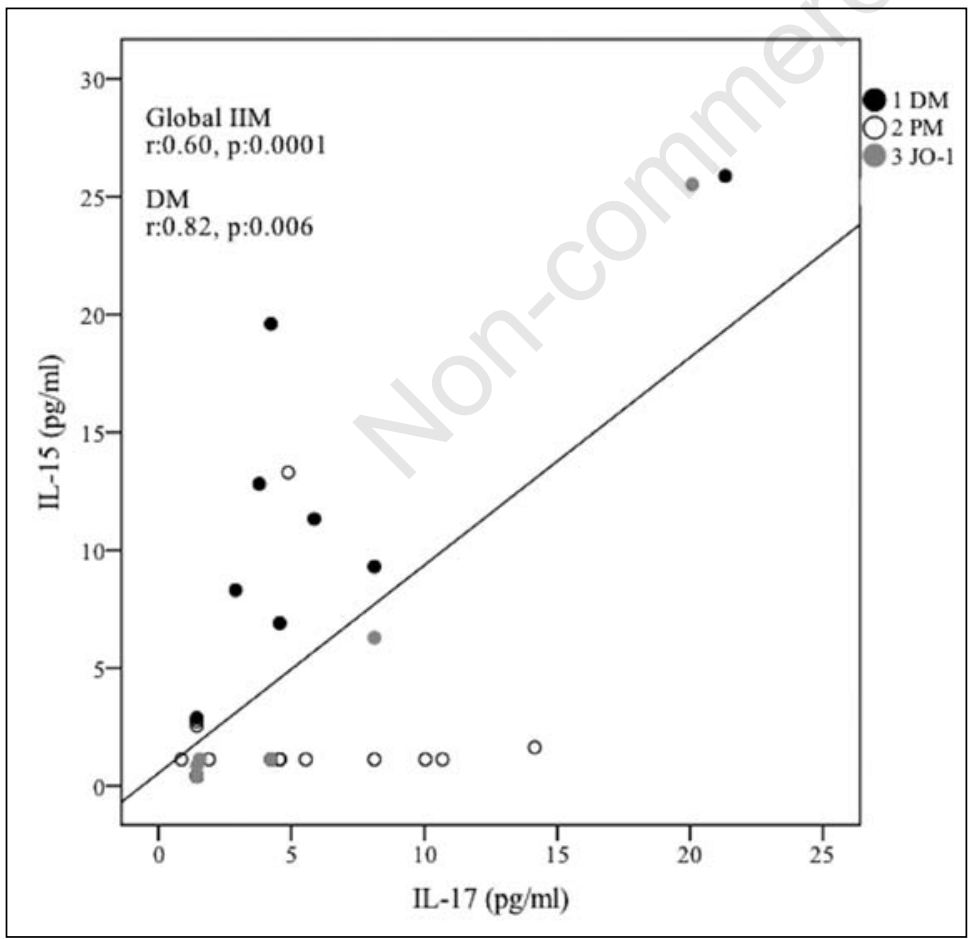

Figure 3 - Correlation analysis between interleukin (IL)-17 and IL-15 serum levels at baseline in all idiopathic inflammatory myopathies (IIM), dermatomyositis (DM) (black close circle), polymyositis (PM) (open circle), and and Jo-1 anti-synthetase syndrome (grey close circle) patients. $(\mathrm{r}=0.30, \mathrm{P}=0.20)$. In all IIM, IL-15 levels were also correlated with MCP-1 $(\mathrm{r}=0.45$, $\mathrm{P}=0.001)$, and MIP- $1 \alpha(\mathrm{r}=0.30, \mathrm{P}=0.03)$. IL-17 also correlated with MIP-1 $\beta(\mathrm{r}=0.55$, $\mathrm{P}=0.0001$ ).

\section{DISCUSSION}

In this study we aimed at evaluating the serum levels of IL-15 and IL-17 in 14 PM, $10 \mathrm{DM}$ and 7 ASS Jo1+ve patients treated in a standard care rheumatology setting, at baseline and after a median follow-up period of 5 months. IL-15 and IL-17 serum levels were also correlated with IL-6, IL10, MCP-1, MIP- $1 \alpha$, MIP- $1 \beta$ serum levels. In addition, we assessed possible correlations between all cytokines serum levels and 5-MMT, HAQ scores and CK concentration.

In agreement with the literature, IIM patients showed higher levels of MCP-1, MIP-1 $\beta$, IL-15 and IL-17 than HC $(6,11$, $21,27,34-39)$. MCP-1 has already been detected either in sera or in muscle tissue (6, 35-37). While DMARDs did not affect cytokines levels, we found a direct correlation between glucorticoid dosage and IL-10 or MIP-1 $\alpha$ levels.

In agreement with many reports, high levels of IL-15 and IL-17 were detected in IIM patients $(11,16,20-22,27,39)$. Unlike a previous study that reported high IL-17 serum levels in early stage disease (27), we found a direct correlation between IL-17 and disease duration. However, differences in serum sampling can account for this discrepancy. We observed, for the first time in IIM patients, that IL-15 and IL-17 serum levels were strongly correlated and that this correlation was not affected by disease duration and therapy.

To date, few and discordant reports concerning comparisons between cytokine serum levels among the different subsets of IIM have been published $(16,40)$. Instead, our study clearly showed that IL-15 serum levels differed significantly among the clinical subsets, being higher in adult DM than PM. In DM the degree of association between IL-15 and IL-17 was even stronger. 
The role of IL-15 and IL-17 in the pathogenesis of IIM is largely unknown, but an interaction between the two cytokines has been demonstrated in RA. IL-17 is strongly expressed in synovial membrane of RA patients (41) and IL-15 is able to stimulate the production of IL-17 by T cells (28). In RA, the uncontrolled release of IL-15, together with the induction of anti-apoptotic signals by Th17 cells, leads to a chronic activation of synoviocytes and progression of the joint damage (42).

Even if RA and IIM are different diseases, IL-15 and IL-17 may also be speculated to have a role in the pathogenesis of IIM. We could envisage that IL-15 and IL-17 mediate the interaction between muscle cells and inflammatory cells.

IL-15 was initially described as an anabolic factor for skeletal muscle, inducing myocyte differentiation and an accumulation of contractile proteins in muscle fibers (43). In IIM muscle, IL-15 is secreted by myoblasts following an interaction between CD40 expressed on myoblasts and CD40L expressed on infiltrating $\mathrm{T}$ cells (38).

However, the expression of IL-15 may depend on the grade of differentiation of the muscle fibers (22). IL-15 synthesis has been found to be increased in PM and DM muscle biopsies (20), and circulating IL-15 levels were higher in patients than in controls $(11,39)$. Recently, IL-15 expression has been demonstrated in macrophages in muscle biopsies from patients with IIM, but not in T cells (22).

Moreover, the IL-15 receptor (IL-15R) has been observed in muscle tissue (20), in particular in mononuclear cell infiltrates and endothelial cells (22).

IL-17, produced by T cells, plays an important role in host defense, inflammation, and autoimmunity (26), and its expression is increased in inflammatory tissues, including IIM (21). Since the identification of Th17 cells in inflamed muscle tissue, IL-17 has been proposed as a co-actor in the immune response that could lead to muscle destruction, and higher serum levels of IL-17 and IL-23, the IL-17 main inducer, have been observed in the sera of PM/DM patients than in HCs (27). Consistently, we found a strong correlation between IL-17 and IL-15 serum levels in IIM patients and we hypothesize that also in IIM IL-15 acts as a strong inducer/regulator of IL-17 synthesis, even if muscle tissue findings are lacking. In addition, exploring the serum levels of IL-15 and IL-17 in patients with amyopathic DM may help the comprehension of their role in the pathogenesis of IIM.

An inverse correlation between baseline IL-17 serum levels and muscle strength, as measured by the 5-MMT, was observed in our study, suggesting that IL-17 might be a potential biomarker of clinical outcome. However, these findings should be interpreted with caution as MMT score did not substantially vary over time in contrast to IL-17 levels.

In addition, follow-up data are available in a small subpopulation and need to be confirmed in larger studies. We did not find a significant correlation between IL15 serum levels and the 5-MMT, while a negative correlation between IL-15 muscle expression and the myositis function index has already been reported, although different samples and muscle strength measurements were used in the two studies (22).

The data we have obtained need to be confirmed in larger cohorts of IIM patients. Our future proposal is to investigate IL-15 and IL-17 serum levels at the disease onset before starting any treatment. A better understanding of the IL-15 and IL-17 interplay, especially in the DM subset, may provide further insights into the pathogenesis of muscle damage and identify novel therapeutic targets.

\section{Key messages}

- IL-15 and IL-17 serum levels are strongly correlated in patients with IIM, especially in DM.

- Higher IL-15 serum levels have been found in DM than in PM.

- A significant inverse correlation has been found between IL-17 levels and MMT scores.

Conflict of interests: the authors declare no conflict of interests. 


\section{REFERENCES}

1. Dalakas MC, Hohlfeld R. Polymyositis and dermatomyositis. Lancet. 2003; 362: 971-82.

2. Mammen AL. Dermatomyositis and polymyositis: clinical presentation, autoantibodies, and pathogenesis. Ann N Y Acad Sci. 2010; 1184: 134-53.

3. Betteridge ZE, Gunawardena H, McHugh NJ. Novel autoantibodies and clinical phenotypes in adult and juvenile myositis. Arthritis Res Ther. 2011; 13: 209.

4. Gunawardena H, Betteridge ZE, McHugh NJ. Newly identified autoantibodies: relationship to idiopathic inflammatory myopathy subsets and pathogenesis. Curr Opin Rheumatol. 2008; 20: 675-80.

5. Gunawardena H, Betteridge ZE, McHugh NJ. Myositis-specific autoantibodies: their clinical and pathogenic significance in disease expression. Rheumatology (Oxford). 2009; 48: 607 12.

6. Baird GS, Montine TJ. Multiplex immunoassay analysis of cytokines in idiopathic inflammatory myopathy. Arch Pathol Lab Med. 2008; 132: 232-8

7. Bilgic H, Ytterberg SR, Amin S, McNallan KT, Wilson JC, Koeuth T, et al. Interleukin-6 and type I interferon-regulated genes and chemokines mark disease activity in dermatomyositis. Arthritis Rheum. 2009; 60: 3436-46.

8. De Paepe B, Creus KK, De Bleecker JL. Role of cytokines and chemokines in idiopathic inflammatory myopathies. Curr Opin Rheumatol. 2009; 21: 610-6.

9. Ernste FC, Reed AM. Idiopathic inflammatory myopathies: current trends in pathogenesis, clinical features, and up-to-date treatment recommendations. Mayo Clin Proc. 2013; 88: 83-105.

10. Kondo M, Murakawa Y, Harashima N, Kobayashi S, Yamaguchi S, Harada M. Roles of proinflammatory cytokines and the Fas/Fas ligand interaction in the pathogenesis of inflammatory myopathies. Immunology. 2009; 128: e589-99.

11. Mielnik P, Chwalinska-Sadowska H, WiesikSzewczyk E, Maslinski W, Olesinska M. Serum concentration of interleukin 15 , interleukin 2 receptor and TNF receptor in patients with polymyositis and dermatomyositis: correlation to disease activity. Rheumatol Int. 2012; 32: 639-43.

12. Nasr R, Reed AM, Peterson EJ. Update: biomarkers for idiopathic inflammatory myopathies. Curr Opin Rheumatol. 2012; 24: 609-15.

13. Rayavarapu S, Coley W, Nagaraju K. An update on pathogenic mechanisms of inflammatory myopathies. Curr Opin Rheumatol. 2011; 23: 579-84.

14. Reed AM, Peterson E, Bilgic H, Ytterberg SR, Amin S, Hein MS, et al. Changes in novel biomarkers of disease activity in juvenile and adult dermatomyositis are sensitive biomarkers of disease course. Arthritis Rheum. 2012; 64: 4078-86.

15. Salomonsson S, Lundberg IE. Cytokines in idiopathic inflammatory myopathies. Autoimmunity. 2006; 39: 177-90.

16. Szodoray P, Alex P, Knowlton N, Centola M, Dozmorov I, Csipo I, et al. Idiopathic inflammatory myopathies, signified by distinctive peripheral cytokines, chemokines and the TNF family members B-cell activating factor and a proliferation inducing ligand. Rheumatology (Oxford). 2010; 49: 1867-77.

17. Tournadre A, Miossec P. Cytokine response in inflammatory myopathies. Curr Rheumatol Rep. 2007; 9: 286-90.

18. Tournadre A, Miossec P. Chemokines and dendritic cells in inflammatory myopathies. Ann Rheum Dis. 2009; 68: 300-4.

19. Zong M, Lundberg IE. Pathogenesis, classification and treatment of inflammatory myopathies. Nat Rev Rheumatol. 2011; 7: 297-306.

20. Sugiura T, Harigai M, Kawaguchi Y, Takagi K, Fukasawa C, Ohsako-Higami S, et al. Increased IL-15 production of muscle cells in polymyositis and dermatomyositis. Int Immunol. 2002; 14: 917-24.

21. Tournadre A, Miossec P. Interleukin-17 in inflammatory myopathies. Curr Rheumatol Rep. 2012; 14: 252-6.

22. Zong M, Loell I, Lindroos E, Nader GA, Alexanderson $\mathrm{H}$, Hallengren $\mathrm{CS}$, et al. Effects of immunosuppressive treatment on interleukin-15 and interleukin-15 receptor $\otimes$ expression in muscle tissue of patients with polymyositis or dermatomyositis. Ann Rheum Dis. 2012; 71: 1055-63.

23. Machado Diaz AC, Chico Capote A, Arrieta Aguero CA, Rodríguez Alvarez Y, García Del Barco Herrera D, Estévez Del Toro M, et al. Proinflammatory soluble interleukin-15 receptor alpha is increased in rheumatoid arthritis. Arthritis. 2012; 2012: 943156.

24. Masuko-Hongo K, Kurokawa M, Kobata T, Nishioka K, Kato T. Effect of IL15 on T cell clonality in vitro and in the synovial fluid of patients with rheumatoid arthritis. Ann Rheum Dis. 2000; 59: 688-94.

25. Raza K, Falciani F, Curnow SJ, Ross EJ, Lee CY, Akbar AN, et al. Early rheumatoid arthritis is characterized by a distinct and transient synovial fluid cytokine profile of $\mathrm{T}$ cell and stromal cell origin. Arthritis Res Ther. 2005; 7: R784-95.

26. Truchetet ME, Mossalayi MD, Boniface K. IL-17 in the rheumatologist's line of sight. Biomed Res Int. 2013; 2013: 295132.

27. Shen H, Xia L, Lu J, Xiao W. Interleukin-17 and interleukin-23 in patients with polymyositis and dermatomyositis. Scand J Rheumatol. 2011; 40: 217-20. 
28. Ziolkowska M, Koc A, Luszczykiewicz G, Ksiezopolska-Pietrzak K, Klimczak E, Chwalinska-Sadowska H, et al. High levels of IL-17 in rheumatoid arthritis patients: IL-15 triggers in vitro IL-17 production via cyclosporin Asensitive mechanism. J Immunol. 2000; 164: 2832-8.

29. Bohan A, Peter JB. Polymyositis and dermatomyositis (first of two parts). N Engl J Med. 1975; 292: 344-7.

30. Bohan A, Peter JB. Polymyositis and dermatomyositis (second of two parts). N Engl J Med. 1975; 292: 403-7.

31. Marguerie C, Bunn CC, Beynon HL, Bernstein RM, Hughes JM, So AK, et al. Polymyositis, pulmonary fibrosis and autoantibodies to aminoacyl-tRNA synthetase enzymes. Q J Med. 1990; 77: 1019-38.

32. Rider LG, Giannini EH, Harris-Love M, Joe $\mathrm{G}$, Isenberg D, Pilkington C, et al. Defining clinical improvement in adult and juvenile myositis. J Rheumatol. 2003; 30: 603-17.

33. Alexanderson $\mathrm{H}$, Lundberg IE, Stenström CH. Development of the myositis activities profile-validity and reliability of a self-administered questionnaire to assess activity limitations in patients with polymyositis/dermatomyositis. J Rheumatol. 2002; 29: 2386-92.

34. Adams EM, Kirkley J, Eidelman G, Dohlman J, Plotz PH. The predominance of beta (CC) chemokine transcripts in idiopathic inflammatory muscle diseases. Proc Assoc Am Physicians. 1997; 109: 275-85.

35. Chen F, Shu XM, Wang DX, Wang GC, Lu $\mathrm{X}$. [Measurement and clinical significance of serum monocyte chemoattractant protein- 1 in patients with polymyosits/dermatomyosits]. Beijing Da Xue Xue Bao. 2012; 44: 204-8.

36. Chinoy H, Salway F, Fertig N, Tait BD, Oddis $\mathrm{CV}$, Ollier WE, et al. Monocyte chemotactic protein-1 single nucleotide polymorphisms do not confer susceptibility for the development of adult onset polymyositis/dermatomyositis in UK Caucasians. Rheumatology (Oxford). 2007; 46: 604-7.

37. Liprandi A, Bartoli C, Figarella-Branger D, Pellissier JF, Lepidi H. Local expression of monocyte chemoattractant protein-1 (MCP-1) in idiopathic inflammatory myopathies. Acta Neuropathol. 1999; 97: 642-8.

38. Sugiura T, Kawaguchi Y, Harigai M, Takagi K, Ohta S, Fukasawa C, et al. Increased CD40 expression on muscle cells of polymyositis and dermatomyositis: role of CD40-CD40 ligand interaction in IL-6, IL-8, IL-15, and monocyte chemoattractant protein-1 production. J Immunol. 2000; 164: 6593-600.

39. Suzuki J, Morimoto S, Amano H, Tokano Y, Takasaki Y, Hashimoto H. Serum levels of interleukin 15 in patients with rheumatic diseases. J Rheumatol. 2001; 28: 2389-91.

40. Król P, Kryštůfková O, Polanská M, Mann H, Klein M, Beran O, et al. Serum levels of interferon $\alpha$ do not correlate with disease activity in patients with dermatomyositis/polymyositis. Ann Rheum Dis. 2011; 70: 879-80.

41. Chabaud M, Fossiez F, Taupin JL, Miossec P. Enhancing effect of IL-17 on IL-1-induced IL-6 and leukemia inhibitory factor production by rheumatoid arthritis synoviocytes and its regulation by Th2 cytokines. J Immunol. 1998; 161: 409-14.

42. Ferraccioli G, Zizzo G. The potential role of Th17 in mediating the transition from acute to chronic autoimmune inflammation: rheumatoid arthritis as a model. Discov Med. 2011; 11: 413-24.

43. Quinn LS, Haugk KL, Grabstein KH. Interleukin-15: a novel anabolic cytokine for skeletal muscle. Endocrinology. 1995; 136: 3669-72. 